\title{
Efficient Protocol for the In Vitro Plantlet Production of Caper (Capparis orientalis Veill.) from the East Adriatic Coast
}

\author{
Snježana Kereša ${ }^{1, *}$, Davor Stanković ${ }^{2}$, Kristina Batelja Lodeta ${ }^{3}$, Ivanka Habuš Jerčić ${ }^{1}$, \\ Snježana Bolarić ${ }^{1}$, Marijana Barić ${ }^{1}$ and Anita Bošnjak Mihovilović ${ }^{1}$ \\ 1 Department of Plant Breeding, Genetics and Biometrics, Faculty of Agriculture, University of Zagreb, \\ Svetošimunska cesta 25, Zagreb 10000, Croatia; ihabus@agr.hr (I.H.J.); sbolaric@agr.hr (S.B.); \\ mbaric@agr.hr (M.B.); amihovilovic@agr.hr (A.B.M.) \\ 2 Faculty of Agriculture, University of Zagreb, Svetošimunska cesta 25, Zagreb 10000, Croatia; \\ stankovicd5@gmail.com \\ 3 Department of Pomology, Faculty of Agriculture, University of Zagreb, Svetošimunska cesta 25, \\ Zagreb 10000, Croatia; kbatelja@agr.hr \\ * Correspondence: skeresa@agr.hr; Tel.: +385-1239-3801
}

Received: 8 May 2019; Accepted: 9 June 2019; Published: 11 June 2019

\begin{abstract}
Caper (Capparis orientalis Veill.) is a species rich in bioactive compounds, with positive effects on human health. It has a great adaptability to harsh environments and an exceptional ability to extract water from dry soils. In Croatia, the caper grows as a wild plant, and its cultivation is insignificant, which is probably due to propagation difficulties. Micropropagation could be a solution for this. The aim of this study was to investigate the success of the micropropagation, in vitro rooting, and acclimatization of Capparis orientalis Veill. Shoot proliferation was tested in a Murashige and Skoog (MS) medium, with sucrose or glucose, and in 13 treatments, presenting the combined effect of different cytokinins and their concentrations. The success of rooting was examined in relation to the impact of various auxins, durations of rooting, and carry-over effects. A better proliferation was achieved when sucrose was used. The highest number (18) of shoots/explants was obtained in the medium supplemented with $0.6 \mathrm{mg} \cdot \mathrm{L}^{-1}$ meta-topolin, while the rooting was equally efficient in the media supplemented with $2 \mathrm{mg} \cdot \mathrm{L}^{-1}$ of indole-3-acetic acid or indole-3-butyric acid, or in hormone-free rooting medium. A prolonged time in the media increased the rooting efficiency, while the carry-over effect had no influence. The acclimatization rate reached $66 \%$. Additional efforts should be made to find out how to speed upthe rooting and enhance the acclimatization rate of caper grown in Croatia.
\end{abstract}

Keywords: caper; micropropagation; rooting; cytokinins; auxins

\section{Introduction}

Caper (Capparis orientalis Veill.) is a species rich in many valuable bioactive compounds, such as flavonoids (rutin, kaempferol) [1], glucosinolates, phenolic acids, and alkaloids, which have allowed potential applications of the caper as a health-promoting plant to be envisaged [2,3]. Several health-improving benefits of caper have been highlighted, especially its anticancerogenic [3] and antioxidant effects [4]. Due to all of its positive effects on human health, caper is a species of great interest for medical purposes and may be considered as a functional food. Caper flower buds, pickled in vinegar or salted, are delicacies that have long been used in culinary traditions. The biggest producers and exporters of caper are Morocco, Tunisia, Egypt, Spain, Italy, Greece, Turkey, and Syria [5]. Caper is 
also cultivated in Australia. The United States and European countries are the biggest consumers of caper [6].

Caper is a xerophilous species, with a great adaptability to harsh environments. This species possesses strong characteristics of adaptation to regions with a fluctuating climate [6]. Under a global warming threat, the Mediterranean region has been highlighted as a climate change hot spot [7]. Very high temperatures and long periods without rain, which are likely to occur in this area, will limit the cultivation of more sensitive cultures, vegetables, and some Mediterranean fruit species, and the cultivation of caper could compensate for this gap by contributing to the diversification of agricultural production. Namely, caper has an exceptional ability to find and extract water from dry and rocky soils, thanks to an extensive root system and a very high root/stem ratio [8], while vegetative canopies cover soil surfaces, which helps to conserve soil water reserves. The caper's root system is associated with a nitrogen-fixing bacteria that allows for growth in soils with poor fertility [9], as well as in salty soils. An additional advantage of caper cultivation is that caper does not burn, so it can be used to help prevent fires spreading more and more often in the Mediterranean region [10].

In the eastern part of the Adriatic Sea, in Croatia, caper grows as a wild plant along the coast and on the islands. The species that are widespread in Croatia are Capparis orientalis Veill. [11,12] and Capparis spinosa L. [13]. Fici S. [14] recognized C. orientalis as Capparis spinosa subsp. rupestris var. rupestris. According to Riviera et al. [15] (pp. 451-455) and Inocencio et al. [11], C. orientalis is probably one of the parents, together with C. sicula, of the hybrid C. spinosa. There are several recognized cultivars of $C$. orientalis growing on the islands of Pantelleria and Salina in Italy and Mallorca in Spain. However, most of the cultivars belong to C. spinosa [16].

In Croatia, there is no significant cultivation of capers, except on stone walls around houses and mostly for a household's own needs. For sale, the caper is usually picked at locations where wild plant populations grow. In addition to the insufficient awareness of the potential of capers as a culture, propagation difficulties may be due to the lack of caper cultivation for commercial purposes. A large number of seedlings are needed to establish a new caper orchard. The most common and simplest method of caper propagation is by fresh seed [17], but growing caper plants from seed is unreliable, as there is great variability in the generative progeny, which is highly evident in terms of the growth habit, yield, quality of flower buds, and vegetative behavior [5].

Vegetative propagation is therefore a better option. Still, it should be noted that conventional clonal propagation is associated with serious rooting problems [18]. Micropropagation has been suggested as a solution, and indeed, the capers of different species and different areas have so far been successfully micropropagated $[5,18-24]$.

For a given area, it is best to use a genotype adapted to the area. The aim of this study was to investigate the success of the micropropagation of the caper (Capparis orientalis Veill.) from the east Adriatic coast by axial branching using different sugars and cytokinins. In vitro rooting efficiency and acclimatization were also tested.

\section{Materials and Methods}

\subsection{In Vitro Culture Establishment}

Healthy young shoots from the wild bushes of Capparis orientalis Veill. were collected in July on the island of Hvar, Croatia. Shoots were cut into pieces with a length of about $5 \mathrm{~cm}$ and subjected to sterilization. The plant material was firstly washed under tap running water for five minutes. Sterilization was carried out by dipping shoots in $70 \%$ ethanol for $2 \mathrm{~min}$ and in $5 \%$ sodium hypochlorite ( $5 \%$ active chlorine), with the addition of $0.1 \%$ Tween 20 for $30 \mathrm{~min}$. The plant material was then washed four times for $5 \mathrm{~min}$ in sterile distilled water. Shoot apices with a size of approximately $1 \mathrm{~mm}$ were aseptically isolated under stereomicroscope, from terminal and lateral buds, and placed on the surface of $10 \mathrm{~mL}$ of the medium for culture establishment (EM) in 12-cm-high tubes. 
EM consisted of MS (Murashige and Skoog [25]) salts and vitamins, 3\% sucrose, $100 \mathrm{mg} \cdot \mathrm{L}^{-1}$ myo-inositol, $0.8 \%$ agar (Difco Bacto), $1.5 \mathrm{mg} \cdot \mathrm{L}^{-1}$ BAP (6-benzylaminopurine), $0.2 \mathrm{mg} \cdot \mathrm{L}^{-1}$ IBA (indole-3-butyric acid) and $0.1 \mathrm{mg} \cdot \mathrm{L}^{-1} \mathrm{GA}$ (gibberellic acid). The $\mathrm{pH}$ was adjusted to 5.8. For the next three cycles of 40 days of the subcultures, conducted in order to produce enough plant material for the experiments, BAP $0.5 \mathrm{mg} \cdot \mathrm{L}^{-1}$ alone was used in the MS medium. Due to bacterial contamination, in the first subculture cycle, an antibiotic cefuroxime at a concentration of $500 \mathrm{mg} \cdot \mathrm{L}^{-1}$ was added to the medium.

\subsection{Shoot Proliferation}

For the shoot proliferation, in vitro shoots established in the MS medium, supplemented with $0.5 \mathrm{mg} \cdot \mathrm{L}^{-1}$ of BAP, were cut into two-nodal stem segments (up to $5 \mathrm{~mm}$ in length) and placed horizontally on a medium with $3 \%$ sucrose or $3 \%$ glucose supplemented with $0.2,0.4$, or $0.6 \mathrm{mg} \cdot \mathrm{L}^{-1}$ $\mathrm{BAP}, \mathrm{ZEA}$ (zeatin), 2iP (2-isopentenyladenine), or the hormone-free (HF) medium. Additionally, in the medium with a sucrose, the influence of $\mathrm{mT}$ (meta-topolin) at $0.2,0.4$, or $0.6 \mathrm{mg} \cdot \mathrm{L}^{-1}$ was examined. The combined effect of the cytokinin type and the concentration in the medium supplemented with $3 \%$ sucrose were considered as treatments. The number of shoots/explant and length of the shoots were recorded 50 days after placing explants in the medium. Only shoots $\geq 5 \mathrm{~mm}$ were considered.

\subsection{Rooting and Acclimatization}

Rooting was investigated through three experiments, in which the following factors that influenced rooting were investigated: (1) type of auxins and their concentrations, (2) durations of rooting, and (3) carry-over effects.

In the first experiment, where the influence of the type of auxins and their concentrations were investigated, the basal rooting medium (MS HFM, hormone-free medium) consisted of MS salts and vitamins, $3 \%$ sucrose, $100 \mathrm{mg} \cdot \mathrm{L}^{-1}$ myo-inositol, and $0.8 \%$ agar (Difco Bacto). Four additional treatments, namely, MS HFM supplemented with IAA (indole-3-acetic acid), at a concentration of $2 \mathrm{mg} \cdot \mathrm{L}^{-1}$ (MS IAA2) or $5 \mathrm{mg} \cdot \mathrm{L}^{-1}$ (MS IAA5), or IBA, at a concentration of $2 \mathrm{mg} \cdot \mathrm{L}^{-1}$ (MS IBA2) or $5 \mathrm{mg} \cdot \mathrm{L}^{-1}$ (MS IBA5), were prepared for this experiment. The shoots were incubated for 70 days.

The second experiment, through which the influence of the duration of rooting for 70 or 85 days on the rooting efficiency was investigated, and the third experiment, lasting for 85 days, in which the influence of the carry-over effect (previous medium) was investigated, were performed on the MSHF, MS IAA2, and MS IBA2 treatments.

In the first and second experiment, shoots that were $0.5-1 \mathrm{~cm}$ long were taken from the medium supplemented with $0.6 \mathrm{mg} \cdot \mathrm{L}^{-1} \mathrm{BAP}$ (as BAP is the most frequently used cytokinin for micropropagation and produced sufficient number of shoots/explant in this concentration) and transferred to the rooting medium. For the third experiment, an additional set of data was recorded from the shoots proliferated in the medium supplemented with $0.6 \mathrm{mg} \cdot \mathrm{L}^{-1}$ of $\mathrm{mT}$.

Recorded traits in all rooting experiments were as follows: the percentage of rooted shoots, length of the longest root, and shoot height. All in vitro experiments were carried out at $23^{\circ} \mathrm{C}$, with a $16 \mathrm{~h}$ photoperiod of cool white light $\left(40 \mu \mathrm{E} \mathrm{m}^{-2} \cdot \mathrm{s}^{-1}\right)$.

Rooted shoots were planted into a mixture of compost and perlite, in a ratio of 2/3:1/3, watered with a $0.15 \%$ solution of fungicide Previcur Energy (Bayer, Leverkusen, Germany), covered with a plastic transparent cover, and acclimatized at $20^{\circ} \mathrm{C}$ under the same light regime.

\subsection{Statistical Analysis}

\subsubsection{Shoot Proliferation}

The influence of the carbohydrate source on the micropropagation efficiency was calculated as the average across the HF medium and media supplemented with $0.6 \mathrm{mg} \cdot \mathrm{L}^{-1}$ cytokinins, except $\mathrm{mT}$. The 
data were recorded from 96 explants (12 Magenta GA-7 vessels containing eight explants) in each type of sugar (sucrose and glucose).

The efficiency of cytokinins and their concentrations (treatments) were recorded from the explants cultured in the medium with sucrose. For this purpose, 72 explants (nine Magenta GA-7 vessels containing eight explants) per cytokinin type were examined ( 24 explants per cytokinin $\times$ concentration combination). The same number of explants was examined in the HF medium.

\subsubsection{Rooting}

The data for the rooting treatments (auxin $\times$ concentration combination), duration of rooting (70 or 85 days), as well as data for the carry-over effect (previously-used cytokinin) were recorded from 45 explants (five Magenta GA-7 vessels each containing nine microshoots) per treatment within the experiment.

The data from shoot proliferation and rooting experiments were subjected to ANOVA. Bonferroni post-hoc test at $p \leq 0.05$ was used for means comparison. To compare the acclimatization rate of plantlets obtained from different rooting media (MS IAA2, MS IBA2, and MS HFM), chi-square tests of independence were computed. The statistical analysis of the data was carried out by the SAS/STAT ${ }^{\circledR}[26]$ program package.

\section{Results and Discussion}

\subsection{Culture Establishment}

Isolated shoot apices successfully started to grow (more than $80 \%$ ), however, bacterial contamination appeared. During the next 40 days of the subculture interval, plant material was grown in the medium containing antibiotic cefuroxime at a concentration of $500 \mathrm{mg} \cdot \mathrm{L}^{-1}$, after which the culture became aseptic. After two additional subcultures, enough shoots were produced in order to set up the experiments.

\subsection{Shoot Proliferation}

\subsubsection{Influence of the Carbohydrate Source}

The sugar type proved to have significant influence on the multiplication efficiency of the caper. The highest number of shoots/explants was obtained when sucrose was used as a carbohydrate (Table 1). Glucose, in this research, was used with the intention to promote the tallest shoots, as was found by Druart [27] for apple rootstock (Malus pumila Mill.) micropropagation, but this was not confirmed for caper. The length of shoots was the same, irrespective of whether sucrose or glucose was supplemented. Moreover, hyperhydration of the basal leaves of the shoots, although not strong, was observed when glucose was used. In Romano et al. [28], it was found that, for cork oak (Quercus suber L.), the highest number of shoots occurred in the medium containing glucose, however, 3\% sucrose induced a similar rate of proliferation and favored shoot elongation. Sucrose and glucose also showed a similar rate of proliferation in sour cherry (Prunus cerasus L.) [29]. Sucrose has almost invariably been found to be the best carbohydrate; glucose is generally found to support growth equally well, and in a few plants, it may result in better in vitro growth than sucrose [30]. Therefore, due to the better proliferation induction, sucrose should be the carbohydrate of choice for caper in vitro propagation. The combined influence of sugar type and the type of cytokinin is shown in Supplementary Table S1. 
Table 1. Micropropagation efficiency, as affected by the sugar type.

\begin{tabular}{lcc}
\hline & No. of Shoots/Explant \pm SE & Average Length of the Shoots \pm SE $(\mathbf{m m})$ \\
\hline Sucrose $(3 \%)$ & $6.5 \pm 0.7^{\mathrm{a}}$ & $8.5 \pm 0.3^{\mathrm{a}}$ \\
Glucose $(3 \%)$ & $4.9 \pm 0.5^{\mathrm{b}}$ & $9.5 \pm 0.8^{\mathrm{a}}$ \\
\hline
\end{tabular}

Means were calculated as average across the hormone-free (HF) medium and the media supplemented with 0.6 $\mathrm{mg} \cdot \mathrm{L}^{-1}$ cytokinins 6-benzylaminopurine (BAP), zeatin (ZEA), or 2-isopentenyladenine (2iP); values within the column followed by the same letter are not significantly different at $p<0.05$; SE: standard error.

\subsubsection{Influence of the Type and Concentration of Cytokinins}

The efficiency of shoot multiplications, as affected by different types and concentrations of cytokinins (treatments), was recorded only for the medium containing sucrose. Based on the results of ANOVA, the type of cytokinin, as well as the concentration of cytokinins, had a significant $(p<0.05)$ influence on the number of new shoots/explants.

BAP is currently the most widely used cytokinin in the micropropagation industry due to its effectiveness and affordability [31]. However, meta-topolin has been an extensively investigated plant growth regulator, and in several studies, it has been described as a more active and better cytokinin than zeatin and benzyladenine in the promotion of shoot formation in plant tissue cultures [31,32]. Interestingly, Bairu et al. [31] found that BA (6-benzyladenine) produced more shoots of Aloe polyphylla at lower concentrations than $\mathrm{mT}$, but as the concentration increased, a larger number of shoots was recorded with the mT. Our results corroborate those of Bairu et al. [31]. Namely, at very low concentrations $\left(0.2\right.$ and $\left.0.4 \mathrm{mg} \cdot \mathrm{L}^{-1}\right)$, BAP and $\mathrm{mT}$ produced similar numbers of new shoots/explants, and as the concentration increased, the differences in the number of shoots increased, with $\mathrm{mT}$ reaching 18 shoots/two-nodal explants in the medium supplemented with $0.6 \mathrm{mg} \cdot \mathrm{L}^{-1} \mathrm{mT}$ (Table 2, Figure 1a). The multiplication in the HF medium was, as expected, the lowest and was similar to the multiplication in the 2iP-supplemented medium.

Table 2. The effect of the type and concentration of cytokinins on shoot multiplication.

\begin{tabular}{|c|c|c|c|}
\hline The Type of Cytokinins & $\begin{array}{l}\text { Concentration of } \\
\text { Cytokinins }\end{array}$ & No. of Shoots/Explant \pm SE & $\begin{array}{l}\text { Average Length of the } \\
\text { Shoots } \pm \text { SE (mm) }\end{array}$ \\
\hline \multirow{3}{*}{$\mathrm{mT}$} & 0.6 & $18.3 \pm 2.4^{\mathrm{a}}$ & $6.2 \pm 0.4$ ef \\
\hline & 0.4 & $13.6 \pm 1.5^{b}$ & $7.0 \pm 0.2$ de \\
\hline & 0.2 & $11.0 \pm 1.3 \mathrm{bcd}$ & $5.4 \pm 0.3^{\mathrm{f}}$ \\
\hline \multirow{3}{*}{ BAP } & 0.6 & $12.2 \pm 1.8^{b c}$ & $7.2 \pm 0.3^{\text {cde }}$ \\
\hline & 0.4 & $10.9 \pm 1.3^{\mathrm{bcd}}$ & $6.4 \pm 0.2^{\text {ef }}$ \\
\hline & 0.2 & $9.9 \pm 1.0^{\mathrm{bcd}}$ & $6.4 \pm 0.3^{\text {ef }}$ \\
\hline \multirow{3}{*}{ ZEA } & 0.6 & $8.5 \pm 1.0^{\text {cde }}$ & $8.1 \pm 0.3^{b c d}$ \\
\hline & 0.4 & $7.3 \pm 0.7$ de & $7.9 \pm 0.4 \mathrm{bcd}$ \\
\hline & 0.2 & $6.2 \pm 0.6^{\text {ef }}$ & $8.5 \pm 0.3^{a b c}$ \\
\hline \multirow{3}{*}{$2 \mathrm{iP}$} & 0.6 & $3.1 \pm 0.2^{\mathrm{fg}}$ & $8.9 \pm 0.5^{a b}$ \\
\hline & 0.4 & $2.8 \pm 0.3 \mathrm{fg}$ & $9.1 \pm 0.6^{\mathrm{ab}}$ \\
\hline & 0.2 & $2.1 \pm 0.3 \mathrm{~g}$ & $9.7 \pm 0.7^{\mathrm{a}}$ \\
\hline $\mathrm{HF}$ & 0 & $2.0 \pm 0.3 \mathrm{~g}$ & $9.9 \pm 1.1^{\mathrm{a}}$ \\
\hline
\end{tabular}

mT: meta-topolin. Values within the column followed by the same letter are not significantly different according to Bonferroni tests at $p<0.05$; SE: standard error. 

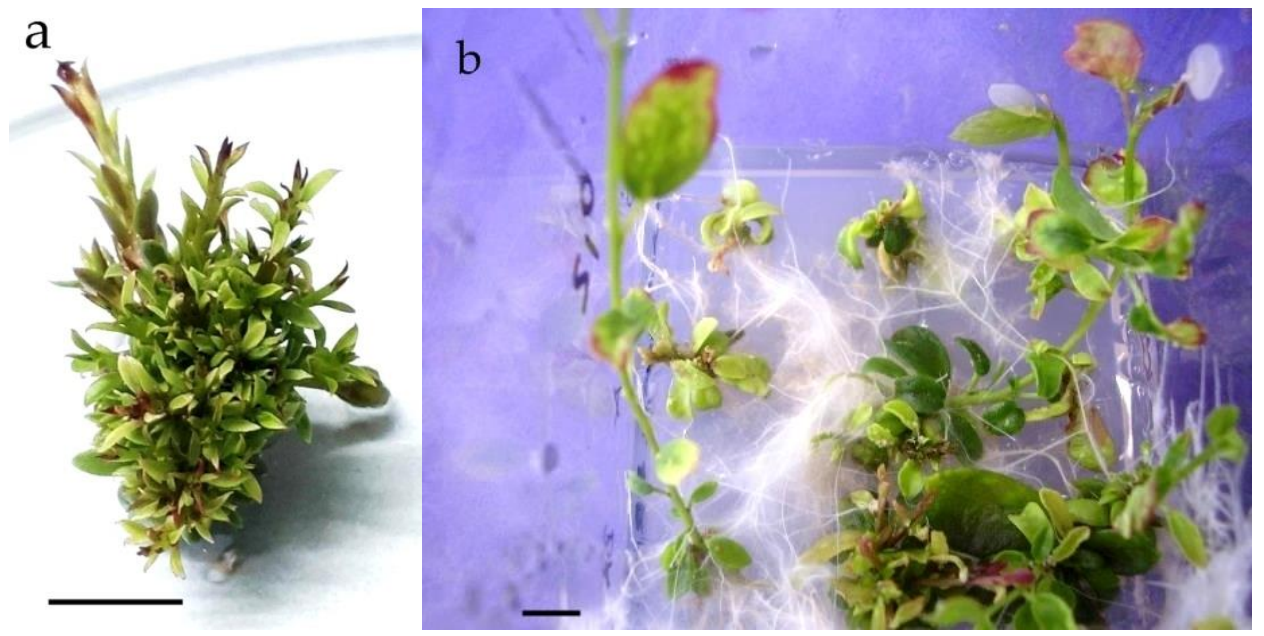

Figure 1. Proliferation of the caper in $0.6 \mathrm{mg} \cdot \mathrm{L}^{-1}$ of $\mathrm{mT}(\mathbf{a})$ and rooting in the MS IAA2 medium (b); bar $=1 \mathrm{~cm}$.

It is well documented that the species from the Capparaceae family have great morphogenic potential, but most micropropagation studies were conducted on Capparis spinosa L. $[5,18,19,33]$ or Capparis decidua [20,24]. Hegazi et al. [22] reported on the micropropagation of two Capparis species from Egypt, C. orientalis and Capparis leucophylla. In this investigation, C. orientalis produced up to 9 axillary shoots/explants after 6 weeks in the culture on MS medium supplemented with $3 \mathrm{mg} \mathrm{mg} \cdot \mathrm{L}^{-1}$ of BA, and an elongation stage of an additional 8 weeks had to be performed due to very short shoots. Using a somewhat prolonged multiplication stage of 50 days, we managed to produce a much higher number of shoots/explants at a low cytokinin (mT or BAP) concentration, and these shoots were long enough to be transferred directly to the rooting medium. Proliferation in the medium supplemented with $0.6 \mathrm{mg} \cdot \mathrm{L}^{-1}$ ZEA (Table 2) as a natural cytokinin was not effective as reported by Chalak and Elbitar [18], who found the best proliferation rate of $C$. spinosa L. subsp. rupestris in the medium supplemented with $1 \mathrm{mg} \cdot \mathrm{L}^{-1}$ of ZEA.

The longest shoots were obtained in the HF medium, the medium supplemented with $2 \mathrm{iP}$, and the medium supplemented with $0.2 \mathrm{mg} \cdot \mathrm{L}^{-1} \mathrm{ZEA}$, while the shortest shoots were produced in the media with BAP and $\mathrm{mT}$ (Table 2). As far as we know, this is the first report on the micropropagation of Capparis orientalis Veill. from the east Adriatic coast and the first report on the use of $\mathrm{mT}$ in caper micropropagation.

\subsection{Rooting and Acclimatization}

\subsubsection{Rooting Efficiency as Influenced by the Type and Concentration of Auxins}

The combinations of the types and concentrations of auxins used in these experiments were chosen due to them having already been used for in vitro rooting of caper in several previous studies $[5,19,21,23]$. Auxins at different concentrations (rooting treatments) significantly $(p<0.05)$ influenced rooting efficiency. The highest percentages of rooted plants were obtained in the media supplemented with $2 \mathrm{mg} \cdot \mathrm{L}^{-1}$ of IAA or IBA, or in MS HFM $(73 \%, 63 \%$, and $58 \%$, respectively) (Table 3, Figure $1 \mathrm{~b}$ ). The longest shoots were obtained in the same media. This is in accordance with the results of Al-Mahmood et al. [23], who also obtained substantially different rooting percentages of C. spinosa in the medium supplemented with $2 \mathrm{mg} \cdot \mathrm{L}^{-1}$ of IAA or IBA. The longest roots were produced in the MS HFM. Difficulty in the rooting of caper shoots is the main obstacle for in vivo caper plant production [17]. The rooting of caper in vitro could also be a difficult task. The highest percentages of the rooted plants after 70 days are comparable with those obtained by Hegazi at al. [22] for $C$. orientalis using $1 \mathrm{mg} \cdot \mathrm{L}^{-1} \mathrm{IBA}+1 \mathrm{mg} \cdot \mathrm{L}^{-1}$ NAA (1-naphthaleneacetic acid). We also tried to use NAA at a concentration of $2 \mathrm{mg} \cdot \mathrm{L}^{-1}$ for rooting microshoots, but we discarded this rooting treatment because of 
the abundant callus formation on the induced roots (data not presented). The same was noticed by Rodríguez et al. [19]. Unlike the results of Hegazi at al. [22] and Al-Mahmood at al. [23], who failed to induce rooting in a hormone-free medium, we found a substantial but not significant difference between the rooting in a medium supplemented with $2 \mathrm{mg} \cdot \mathrm{L}^{-1}$ of auxins and MS HFM. A significant decrease in the percentage of the rooted plants was, however, recorded when the auxin concentration was elevated to $5 \mathrm{mg} \cdot \mathrm{L}^{-1}$ (Table 3). Similar to our results, Carra et al. [5] found a decrease in the rooting efficiency or even a failure of the caper (C. spinosa) microshoot rooting, upon elevating IBA or IAA from 5 to $10 \mu \mathrm{M}$ under light exposure, as we had. It has to be mentioned that the use of a half-strength MS medium, which boosts the rooting of some species, decreased the percentage of rooting by about $20 \%$ and reduced several other parameters, such as root length and shoot height (data not presented). The same negative effect of the "diluted" medium on the rooting efficiency was recorded by Hegazi et al. [22].

Table 3. Influence of the auxin type and concentration on the rooting efficiency.

\begin{tabular}{cccc}
\hline Rooting Treatments & $\begin{array}{c}\text { * Percentage of Rooting } \pm \\
\text { SE (\%) }\end{array}$ & $\begin{array}{c}\text { Root Length } \pm \text { SE } \\
(\mathbf{m m})\end{array}$ & $\begin{array}{c}\text { Shoot Height } \pm \text { SE } \\
(\mathbf{m m})\end{array}$ \\
\hline MS IAA2 & $73 \pm 5.5^{\mathrm{a}}$ & $22 \pm 1.5^{\mathrm{a}}$ & $27 \pm 1.8^{\mathrm{a}}$ \\
MS IBA2 & $63 \pm 4.2^{\mathrm{ab}}$ & $18 \pm 1.9^{\mathrm{a}}$ & $23 \pm 1.8^{\mathrm{ab}}$ \\
MS IAA5 & $44 \pm 7.1^{\mathrm{b}}$ & $14 \pm 2.7^{\mathrm{ab}}$ & $15 \pm 1.1^{\mathrm{c}}$ \\
MS IBA5 & $22 \pm 6.8^{\mathrm{c}}$ & $5 \pm 0.1^{\mathrm{b}}$ & $19 \pm 2.9^{\mathrm{bc}}$ \\
MS HFM & $58 \pm 4.1^{\mathrm{ab}}$ & $26 \pm 4.2^{\mathrm{a}}$ & $22 \pm 1.5^{\mathrm{ab}}$ \\
\hline
\end{tabular}

* Data were recorded after 70 days in the rooting medium. Values within the column followed by the same letter are not significantly different according to Bonferroni tests at $p<0.05$; SE: standard error.

In addition to the highest percentage of rooted shoots, MS IAA2, MS IBA2, and MS HFM favored the elongation of shoots during rooting, which later could contribute to better acclimatization. Namely, even if the shoot tip decayed during the first days of acclimatization, higher plantlets branched from basal nodes and successfully acclimatized (Figure 2). A high survival rate during hardening when using plantlets with a length of $3 \mathrm{~cm}$, in comparison to shorter plantlets, was also reported by Chalak and Elbitar [18].

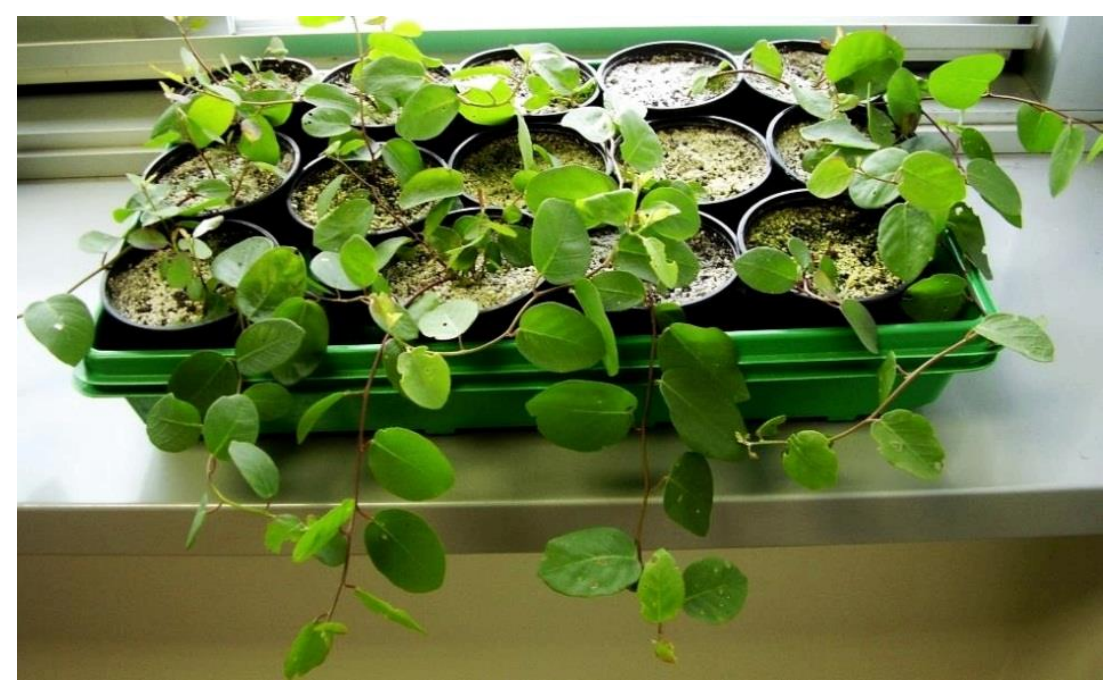

Figure 2. Acclimatized plants, five months after being transplanted into pots.

\subsubsection{Rooting Efficiency as Influenced by the Time Spent in the Rooting Medium}

The average rooting percentage, recorded after 70 days in the rooting medium, was not satisfactory, so a prolonged time of rooting was examined. The results shown in Table 4 and Supplementary Table 
S2 clearly demonstrate that the prolongation of the rooting time for 15 days resulted in a significantly higher percentage of rooted shoots. The shoot height also significantly increased in comparison to the shorter incubation time. It remains to be investigated whether modifying the rooting procedures (e.g., incubating the shoots for a few days in the dark and then transmitting them to the light) would contribute to an increase in the percentage of rooted shoots of $C$. orientalis and perhaps result in a shorter time for sufficient rooting to occur. Such a procedure significantly increased the rooting percentage of C. spinosa in the medium supplemented with the $10 \mu \mathrm{M}$ IBA [5].

Table 4. Influence of the time spent in the rooting media on the rooting efficiency.

\begin{tabular}{cccc}
\hline Duration of Rooting & Percentage of Rooting \pm SE & Root Length \pm SE $(\mathbf{m m})$ & Shoot Height \pm SE $(\mathbf{m m})$ \\
\hline 70 days & $62 \pm 3.6^{\mathrm{b}}$ & $20 \pm 2.0^{\mathrm{a}}$ & $23 \pm 1.2^{\mathrm{b}}$ \\
85 days & $85 \pm 3.2^{\mathrm{a}}$ & $24 \pm 2.0^{\mathrm{a}}$ & $36 \pm 2.3^{\mathrm{a}}$ \\
\hline
\end{tabular}

Means were calculated as the average of the MSHF, MS IAA2, and MS IBA2 treatments during rooting; values within the column followed by the same letter are not significantly different at $p<0.05$; SE: standard error.

\subsubsection{Rooting Efficiency as Affected by the Carry-Over Effect}

A high level of endogenous cytokinin is required for the induction of the initial cell divisions. These early cell divisions are a prerequisite for root formation. However, cytokinins are also involved in regulating the direction of development. They block root meristemoid development by enhancing unorganized cell divisions in cells that would otherwise form root meristemoids [34]. Therefore, cytokinins may be considered as auxin antagonists, because they often reduce the effects of auxins. Cytokinins are, however, important in tuning auxin transport and biosynthesis [35]. Bollmark et al. [36] report that, during root formation, the endogenous cytokinin content transiently decreases, but some cytokinins are more stable than others. BA (BAP) produces extremely stable derivatives, such as [9G]BA, which is suspected to inhibit rooting post vitro, while $\mathrm{mT}$ and its derivatives do not inhibit in vitro formation, and their breakdown is relatively fast [37]. Gentile et al. [38] found a higher rooting percentage in Prunus rootstocks when the culture was proliferated in $\mathrm{mT}$ before the rooting induction. However, this was the case for only one genotype; the other rooted equally well, irrespective of whether it was proliferated in $\mathrm{mT}$ or BAP. In this study, there was no significant difference in the rooting efficiency between the microshoots previously proliferated in the two different cytokinins, BAP and $\mathrm{mT}$ (Table 5). The reason for this could be the very low concentration $\left(0.6 \mathrm{mg} \cdot \mathrm{L}^{-1}\right)$ of cytokinins used during the proliferation phase. Werbrouck et al. [37] also found that there was no difference in rooting between the plants developed in the cytokinin-free medium and those developed in the medium supplemented with $5 \mu \mathrm{M}$ BA or mT. However, the plants developed in the medium with 10 or more $\mu \mathrm{M} \mathrm{mT}$ rooted better during acclimatization than the plants developed in the medium with an equimolar concentration of BA.

Table 5. Influence of the cytokinin type in the previous medium for proliferation on the rooting efficiency (carry-over effect).

\begin{tabular}{cccc}
\hline Cytokinin in Previous Medium & Percentage of Rooting \pm SE (\%) & Root Length \pm SE (mm) & Shoot Height \pm SE (mm) \\
\hline BAP & $85 \pm 3.2^{\mathrm{a}}$ & $24 \pm 2.0^{\mathrm{a}}$ & $36 \pm 2.2^{\mathrm{a}}$ \\
mT & $77 \pm 4.2^{\mathrm{a}}$ & $23 \pm 2.2^{\mathrm{a}}$ & $39 \pm 2.2^{\mathrm{a}}$ \\
\hline
\end{tabular}

Means were calculated as the average of the MSHF, MS IAA2, and MS IBA2 treatments during rooting. Data were recorded after 85 days in the rooting medium. Values within the column followed by the same letter are not significantly different at $p<0.05$; SE: standard error.

The rate of surviving plants during acclimatization was $66 \%, 59 \%$, and $56 \%$ for the plantlets rooted in MS IBA2, MS IAA2, and MSHF medium, respectively, and does not differ statistically based on a chi-squared test $(p<0.05)$. The survival rate obtained is in accordance with the results obtained by Musallam et al. [21], although other authors reported a higher acclimatization rate for micropropagated 
C. spinosa (Carra et al.; Al-Mahmood et al. [5,23]), C. spinosa subsp. rupestris (Chalak and Elbitar [18]), and C. orientalis (Hegazi et al. [22]).

\section{Conclusions}

A very efficient in vitro proliferation of 18 shoots/two-nodal stem segments was achieved for $C$. orientalis using a low concentration $\left(0.6 \mathrm{mg} \cdot \mathrm{L}^{-1}\right)$ of $\mathrm{mT}$. This is the first report on the use of $\mathrm{mT}$ for C. orientalis micropropagation. A similar percentage of in vitro-rooted plantlets after 70 days were obtained using MS media supplemented with $2 \mathrm{mg} \cdot \mathrm{L}^{-1}$ IAA (73\%), $2 \mathrm{mg} \cdot \mathrm{L}^{-1}$ IBA (63\%), or MS HFM (58\%). Increasing the concentration to $5 \mathrm{mg} \cdot \mathrm{L}^{-1}$ of these auxins suppressed root formation. The prolongation of the root induction time from 70 to 85 days significantly increased the percentage of rooted plantlets to $85 \%$. Shoots proliferated in BAP or $\mathrm{mT}$, rooting similarly, suggesting that, due to the low concentration of cytokinins, there was no negative effect of BAP derivatives on root formation. The acclimatization rate reached $66 \%$ for the plants rooted in MS IBA2 medium; similar results were found for plants rooted in MS IAA2 and MS HFM. It remains, therefore, to find out how to speed up the rooting and enhance the acclimatization rate of micropropagated $C$. orientalis from the east Adriatic coast.

Supplementary Materials: The following are available online at http://www.mdpi.com/2073-4395/9/6/303/s1. Table S1: The combined influence of sugar type and type of cytokinins on the multiplication efficiency and length of the shoots. Table S2: Rooting efficiency as affected by rooting medium after 85 days of incubation.

Author Contributions: Conceptualization: S.K., K.B.L., and A.B.M.; methodology and data analysis: S.K. and A.B.M.; experiments and measurements: D.S., A.B.M., and I.H.J.; writing—original draft preparation: S.K.; review and editing: S.B., M.B., A.B.M., and K.B.L.

Funding: This research was funded by the University of Zagreb's financial support for scientific research.

Conflicts of Interest: The authors declare no conflict of interest.

\section{References}

1. Inocencio, C.; Rivera, D.; Alcaraz, F.; Tomás-Barberán, F.A. Flavonoid content of commercial capers (Capparis spinosa, C. sicula and C. orientalis) produced in mediterranean countries. Eur. Food Res. Technol. 2000, 212, 70-74. [CrossRef]

2. Anwar, F.; Muhammad, G.; Hussain, M.A.; Zengin, G.; Alkharfy, K.M.; Ashraf, M.; Gilani, A.H. Capparis spinosa L.: A plant with high potential for development of functional foods and nutraceuticals/pharmaceuticals. Int. J. Pharmacol. 2016, 12, 201-219. [CrossRef]

3. Kulisic-Bilusic, T.; Schmöller, I.; Schnäbele, K.; Siracusa, L.; Ruberto, R. The anticarcinogenic potential of essential oil and aqueous infusion from caper (Capparis spinosa L.). Food Chem. 2012, 132, 261-267. [CrossRef] [PubMed]

4. Kalantari, H.; Foruozandeh, H.; Khodayar, M.J.; Siahpoosh, A.; Saki, N.; Kheradmand, P. Antioxidant and hepatoprotective effects of Capparis spinosa L. fractions and Quercetin on tert-butyl hydroperoxide-induced acute liver damage in mice. J. Tradit. Complement. Med. 2018, 8, 120-127. [CrossRef] [PubMed]

5. Carra, A.; Del Signore, M.A.; Sottile, F.; Ricci, A.; Carimi, F. Potential use of new diphenylurea derivatives in micropropagation of Capparis spinosa L. Plant Growth Regul. 2012, 66, 229-237. [CrossRef]

6. Chedraoui, S.; Abi-Rizk, A.; El-Beyrouthy, M.; Chalak, L.; Ouaini, N.; Rajjou, L. Capparis spinosa L. in a systematic review: A xerophilous species of multi values and promising potentialities for agrosystems under the threat of global warming. Front. Plant. Sci. 2017, 8, 1845. [CrossRef] [PubMed]

7. Pachaury, R.K.; Allen, M.R.; Barros, V.R.; Broome, J.; Cramer, W.; Christ, R.; Church, J.A.; Clarke, J.; Dahe, Q.; Dasgupta, P.; et al. Climate Change 2014: Synthesis Report. In Contribution of Working Groups I, II and III to the Fifth Assessment Report of the Intergovernmental Panel on Climate Change; Pachauri, R., Meyer, L., Eds.; IPCC: Geneva, Switzerland, 2014; p. 151. Available online: http://www.ipcc.ch (accessed on 11 April 2019).

8. Gan, L.; Zhang, C.; Yin, Y.; Lin, Z.; Huang, Y.; Xiang, J.; Fu, C.; Li, M. Anatomical adaptations of the xerophilous medicinal plant, Capparis spinosa, to drought conditions. Hortic. Environ. Biotechnol. 2013, 54, 156-161. [CrossRef] 
9. Andrade, G.; Esteban, E.; Velasco, L.; Lorite, M.J.; Bedmar, E.J. Isolation and identification of N2-fixing microorganisms from the rhizosphere of Capparis spinosa (L.). Plant Soil 1997, 197, 19-23. [CrossRef]

10. Neyisci, T. A study on the slow burning plant species suitable for controlling forest fires' (in Turkish, summary in English). Turk. J. Agric. For. 1987, 11, 595-604.

11. Inocencio, C.; Rivera, D.; Obon, M.C.; Alcaraz, F.; Barrena, J.A. A systematic revision of Capparis section Capparis (Capparaceae). Ann. MO. Bot. Gard. 2006, 93, 122-149. [CrossRef]

12. Nikolić, T. Flora Croatica Data Base. Faculty of Science, University of Zagreb. 2015. Available online: http://hirc.botanic.hr/fcd (accessed on 12 April 2019).

13. Mitić, B.; Topić, J.; Ilijanić, L.; Jasprica, N.; Milović, M.; Ruščić, M. Kartiranje flore Dalmacije. Prioritetna područja: Otok Pag, estuarij Krke, otok Vis i pučinski otoci, Pelješac i Mljet, tok Cetine; University of Zagreb: Zagreb, Croatia, 2009.

14. Fici, S. A taxonomic revision of the Capparis spinosa group (Capparaceae) from the Mediterranean to Central Asia. Phytotaxa 2014, 174, 001-024. [CrossRef]

15. Rivera, D.; Alcaraz, F.; Inocencio, C.; Oboón, C.; Carreño, E. Taxonomic study of cultivated Capparis sect. Capparis in the western Mediterranean. In Taxonomy of Cultivated Plants; Andrews, S., Leslie, A.C., Alexander, C., Eds.; Royal Botanic Gardens: Kew, UK, 1999; pp. 451-455.

16. Riviera, D.; Inocencio, C.; Oboón, C.; Alcaraz, F. Review of food and medicinal uses of Capparis, L. subgenus Capparis (Capparidaceae). Econ. Bot. 2003, 57, 515-534. [CrossRef]

17. Ramezani-Gask, M.; Bahrani, M.J.; Shekafandeh, A.; Salehi, H.; Taghvaei, M.; Majid Al-Ahmadi, J. A comparison of different propagation methods of common caper-bush (Capparis spinosa L.) as a new horticultural crop. Int. J. Plant Dev. Biol. 2008, 2, 106-110.

18. Chalak, L.; Elbitar, A. Micropropagation of Capparis spinosa L. subsp. rupestris Sibth \& Sm. by nodal cuttings. Indian J. Biotechnol. 2006, 5, 555-558.

19. Rodríguez, R.; Rey, M.; Cuozzo, L.; Ancora, G. In vitro propagation of caper (Capparis spinosa L.). Vitr. Cell. Dev. Biol. 1990, 26, 531-536.

20. Tyagi, P.; Kothari, S.L. Micropropagation of Capparis decidua through in vitro shoot proliferation on nodal explants of mature tree and seedling explants. J. Plant Biochem. Biotechnol. 1997, 6, 19-23. [CrossRef]

21. Musallam, I.; Duwayri, M.; Shibli, R.A. Micropropagation of caper (Capparis spinosa L.) from wild plants. Funct. Plant Sci. Biotechnol. 2010, 5, 17-21.

22. Hegazi, A.G.; Eid, S.R.; Sharaf, A.E.M.M. Micropropagation for conservation of two rare Capparis species from Egypt. Catrina 2011, 6, 29-39.

23. Al-Mahmood, H.J.; Shatnawi, M.A.; Shibli, R.A.; Makhadmeh, I.M.; Abubaker, S.M.; Shadiadeh, A.N. Clonal propagation and medium-term conservation of Capparis spinosa: A medicinal plant. J. Med. Plants Res. 2012, 6, 3826-3836.

24. Siddique, I.; Bukhari, N.A.W. Synthetic seed production by encapsulation nodal segments of Capparis decidua (Forsk.), in vitro regrowth of plantlets and their biochemical studies. Agrofor. Syst. 2018, 92, 1711-1719. [CrossRef]

25. Murashige, T.; Skoog, F. A revised medium for rapid growth and bioassay with tobacco tissue culture. Physiol. Plant. 1962, 15, 473-497. [CrossRef]

26. SAS/STATßSoftware Version [9.4] 2002-2012; SAS Institute Inc.: Cary, NC, USA, 2013.

27. Druart, P. C-source and growth response of Prunus glandulosa 'Sinensis? Thund. and Malus pumila Mill. M26 and M9 clone during in vitro propagation. Bull. Rech. Agron. Gembloux 1995, 30, $29-37$.

28. Romano, A.; Noronha, C.; Martins-Loução, M.A. Role of carbohydrates in micropropagation of cork oak. Plant Cell Tissue Organ. Cult. 1995, 40, 159-167. [CrossRef]

29. Borkowska, B.; Szczerba, J. Influence of different carbon sources on invertase activity and growth of sour cherry (Prunus cerasus L.) shoot cultures. J. Exp. Bot. 1991, 42, 911-915.

30. Thorpe, T.; Stasolla, C.; Yeung, E.C.; de Klerk, G.-J.; Roberts, A.; George, E.F. The Components of Plant Tissue Culture Media II: Organic Additions, Osmotic and pH Effects, and Support Systems. In Plant Propagation by Tissue Culture, 3rd ed.; George, E.F., Hall, M.A., De Klerk, G.-J., Eds.; Springer: Dordrecht, The Netherlands, 2008; pp. 115-173.

31. Bairu, M.W.; Stirk, W.A.; Dolezal, K.; Van Staden, J. Optimizing the micropropagation protocol for the endangered Aloe polyphylla: Can meta-Topolin and its derivatives serve as replacement for benzyladenine and zeatin? Plant Cell Tissue Organ. Cult. 2007, 90, 15-23. [CrossRef] 
32. Kubaláková, M.; Strnad, M. The effects of aromatic cytokinins on micropropogation and regeneration of sugar beet in vitro. Biol. Plant. 1992, 34, 578-579.

33. Al-Safadi, B.; Elias, R. Improvement of caper (Capparis spinosa L.) propagation using in vitro culture and gamma irradiation. Sci. Hortic. 2011, 127, 290-297. [CrossRef]

34. De Klerk, G.J.; Hanecakova, J.; Jasik, J. The role of cytokinins in rooting of stem slices from apple microcuttings. Plant Biosyst. 2001, 135, 79-84. [CrossRef]

35. Della Rovere, F.; Fattorini, L.; D’Angeli, S.; Veloccia, A.; Falasca, G.; Altamura, M.M. Auxin and cytokinin control formation of the quiescent centre in the adventitious root apex of Arabidopsis. Ann. Bot. 2013, 112, 1395-1407. [CrossRef] [PubMed]

36. Bollmark, M.; Kubát, B.; Eliasson, L. Variation in endogenous cytokinin content during adventitious root formation in pea cuttings. Plant Physiol. 1988, 132, 262-265. [CrossRef]

37. Werbrouck, S.P.O.; Strnad, M.; Van Onckelen, H.A.; Debergh, P.C. Meta-Topolin, an alternative to benzyladenine in tissue culture? Physiol. Plant. 1996, 98, 291-297. [CrossRef]

38. Gentile, A.; Jàquez Gutiérrez, M.; Martinez, J.; Frattarelli, A.; Nota, P.; Caboni, E. Effect of meta-Topolin on micropropagation and adventitious shoot regeneration in Prunus rootstocks. Plant Cell Tissue Organ. Cult. 2014. [CrossRef]

(C) 2019 by the authors. Licensee MDPI, Basel, Switzerland. This article is an open access article distributed under the terms and conditions of the Creative Commons Attribution (CC BY) license (http://creativecommons.org/licenses/by/4.0/). 